\title{
The Words We Use and The Worlds We Build
}

\author{
Sophie Duncan ${ }^{1^{*}}$ \\ ${ }^{1}$ Department of Geography, University of British Columbia, Vancouver, Canada. \\ sophiesduncan@gmail.com
}

Received July 9, 2017

OPEN ӘACCESS

Accepted July 20, 2017

DOI 10.14237/ebl.9.1.2018.1045

Copyright (c) 2018 by the author(s); licensee Society of Ethnobiology. This is an open-access article distributed under the terms of the Creative Commons Attribution-NonCommercial 4.0 International Public License (https://creativecommons.org/licenses/by-nc/4.0), which permits non-commercial use, distribution, and reproduction in any medium, provided the original author and source are credited.

Alien.

Invasive.

Nuisance.

Foreign.

Noxious.

Non-native.

Exotic.

Native.

I am a white Arizonan who grew up during SB1070, the racist and xenophobic "show me your papers" legislation that tore families and communities apart. The Arizona legislature designed SB1070, the Support Our Law Enforcement and Safe Neighborhoods Act, to facilitate racial profiling by allowing law enforcement to ask for legal status and documents based on "reasonable suspicion" (American Civil Liberties Union 2017; National Public Radio 2016). Many states in America used SB1070 as a model for their immigration legislation.

I also grew up in a community where voters elected former Sheriff Joe Arpaio, a law enforcement official who built his reputation based on antiimmigrant rhetoric, barbaric treatment of people who are incarcerated, and predatory immigration raids (National Public Radio 2016). Arizona voters elected Joe Arpaio for six terms before losing to Paul Penzone in the Fall of 2016 and receiving a conviction of criminal contempt in federal court in 2017 for racial profiling (for which he was pardoned in August of 2017 by the President of the United States one week after the deadly white supremacist rally in Charlottesville, Virginia) (The New York Times 2017). Despite his losses in the recent election and in court, his legacy has had a lasting impact. He destroyed families and communities through incarcera- tion and deportation (Mother Jones 2010). He further dehumanized members of the undocumented community by referring to them as "illegals" during his 24 years in office (Color Lines 2012; National Public Radio 2013; The New York Times Magazine 2015; Think Progress 2015). At a young age, I learned how this type of language chafed against and eroded any recognition of community members' humanity.

I see echoes of the words and acts of Sheriff Joe Arpaio and Arizona legislators in textbooks and scientific literature. As a student, scientist, and gardener, I was encouraged to embrace and use vocabulary produced by European invaders. We need to acknowledge the limitations of this vocabulary and create a language that accurately reflects scientific history. Biologists shaped European colonization and European colonization shaped the future of biology. Colonization created racialized concepts of who is "native" to America and who is not, an "us versus them" mentality predicated on white supremacy. Identifying plants pre-1492 as "native" and post-1492 as "non-native" establishes a false narrative that American natural history began with the European invasion. The invaders claimed and named plants, cementing themselves as the "discoverers" of American flora. The "native plants" they "discovered" have over the course of several generations become "theirs" to protect-a convenient white, settler amnesia. Although the terms non-native, invasive, exotic, and alien refer to plants introduced along with or after the European invasion, the non-native people who invaded, and other white settlers since, do not view themselves as exotic or alien. The use of this language by settlers reinforces a land-ownership history that masks the reality of land-dispossession perpetrated through violence, slavery, and genocide. 


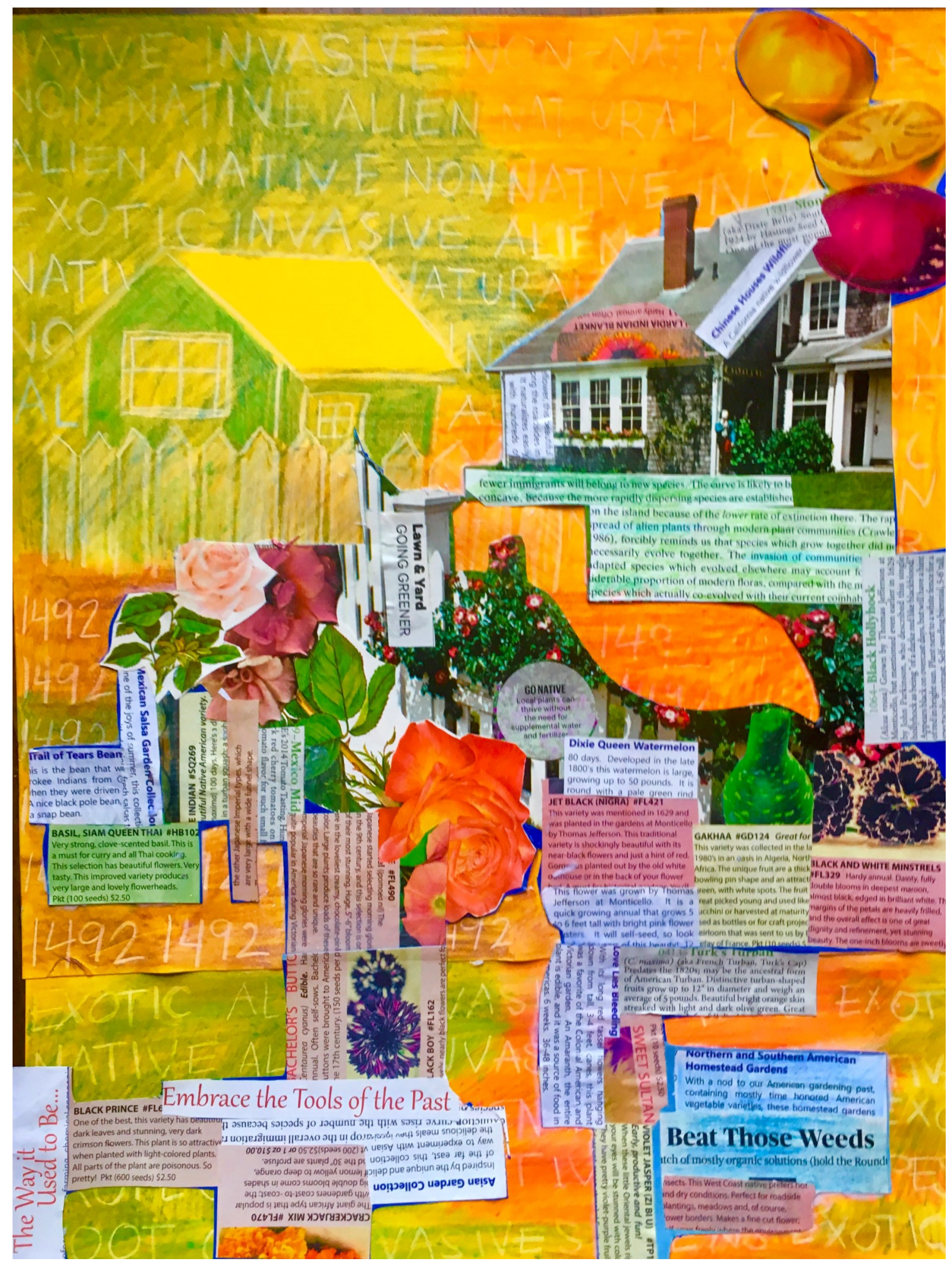

Figure 1 The Words We Use and the Walls We Build is a collage made in the spring of 2017 and draws on source material from gardening magazines, ecology texts, and heirloom seed catalogues. This piece reflects how the white-picket fence American "dream" and the discourse about native and non-native plants embodies the violent, anti-immigrant, and racist rhetoric heard across America. The images included in this collage come from catalogues and magazines such as Better Homes and Gardens, Baker Creek Heirloom Seeds, and Annie's Heirloom Seeds. 
Continued use of and reliance on the language of European invaders reinforces oppressive nationalism and misplaced patriotism. As a plant scientist who has worked with native plant programs, I am familiar with a problematic yet dominant trope: We must protect our native landscape from foreigners. In both scientific and gardening communities, restoring landscapes with native plants has become a priority. I support this restoration effort but find the language associated with native plants problematic because the rhetoric I regularly hear mirrors the xenophobic and racist language endemic to the United States.

The vocabulary used to describe plants is similar to derisive language frequently used by white settlers in reference to indigenous people, people of color, non-European immigrants, and refugees. Additionally, seed catalogues exotify plants from other countries using pejorative language. For example, plants are described as "little Oriental jewels," "Black and White Minstrel Flowers," and "Turk's Turban." Moreover, while employing marginalizing language to discuss plants from other countries, gardening magazines also rely on offensive slogans like "Go Native" to encourage gardeners to buy native plants. While some seed varieties' such as "Cherokee Trail of Tears Bean" acknowledge the violent history of land dispossession in America, other varieties allude to use by Native Americans without acknowledging this past.

In the accompanying art piece (Figure 1), I also selected several seed varieties listed in heirloom seed catalogues that reflect racist and xenophobic language. Thomas Jefferson, one of America's founding presidents, although often renowned as a progressive political thinker and skilled gardener, operated a plantation that profited from the labor of enslaved people. Some of the descriptions of seed varieties featured in Figure 1, advertise the fact that Jefferson cultivated these varieties at his personal residence and plantation, Monticello (Smithsonian Magazine 2012). These catalogues romanticize Jefferson's gardening to promote sales. However, these advertisements fail to acknowledge that Jefferson was a slave owner who relied on the labor of enslaved people to operate his plantation. Heirloom seed catalogues use phrases like "the way things were" and "tools of the past" to profit from a bucolic fable of American farming that erases the relationship between agriculture, land dispossession, and slavery.

The connection I see between SB1070, former Sheriff Joe Arpaio's law enforcement policies, and plant vocabularies is not arbitrary. America's current leadership seeks to build walls. It is true that walls can be made of chain-link, cement, or brick and mortar, but words can also create walls. It is unethical to ignore how scientific and gardening communities uphold and reinforce walls of their own. We need to stop relying on exclusionist and xenophobic vocabulary and sentiments. We have a responsibility to develop a vocabulary that resists violent rhetoric. A friend once explained to me that words have mass, especially if they are written down. They have a weight in this world. While we can calculate the scientific meaning of words like "invasive" in terms of its ecological impact, these words carry an additional weight: the weight of xenophobia, racism, and settler colonialism.

\section{References Cited}

American Civil Liberties Union. 2017. Arizona's SB 1070. Available at: https://www.aclu.org/issues/ immigrants-rights/state-and-local-immigrationlaws/arizonas-sb-1070? redirect $=$ feature/arizonassb-1070. Accessed on June 28, 2017.

Color Lines. 2012. The People of Arizona Won't Comply with Hate. June 26, 2012. Available at: http://www.colorlines.com/articles/peoplearizona-wont-comply-hate. Accessed on July 29, 2017.

Mother Jones. 2010. Did Sheriff Joe Arpaio's AntiImmigrant Zeal Kill David de la Fuente? Available at: http://www.motherjones.com/ politics $/ 2010 / 08 /$ sheriff-joe-arpaio-maricopacounty-sb-1070/. Accessed on May 4, 2017.

National Public Radio. 2013. In Immigration Debate Undocumented vs Illegal Is More Than Just Semantics. January 30, 2013. Available at: http:// www.npr.org/sections/ itsallpolitics/2013/01/30/170677880/inimmigration-debate-undocumented-vs-illegal-ismore-than-just-semantics. Accessed on May 2, 2017.

National Public Radio. 2016. Deal is Reached on Arizona's Hardline Immigration Law, After 6-Year Fight. September 16, 2016. Available at: http:// www.npr.org/sections/thetwoway/2016/09/16/494245921/deal-is-reached-onarizonas-hardline-immigration-law-after-6-yearfight. Accessed on July 1, 2017. 
National Public Radio. 2017. 'America's Toughest Sheriff' Joe Arpaio Goes on Trial. June 26, 2017. Available at: http:// www.npr.org/2017/06/26/534381348/americassheriff-or-community-destroyer-joe-arpaio-goeson-trial. Accessed on June 28, 2017.

Smithsonian Magazine. 2012. "Paradox of Liberty" Tells the Other Side of Jefferson's Monticello. January 31, 2012. Available at: http:// www.smithsonianmag.com/smithsonianinstitution/paradox-of-liberty-tells-the-other-sideof-jeffersons-monticello-83738466/. Accessed on July 20, 2017.

The New York Times Magazine. 2015. The Unwelcome Return of "Illegals". August, 18, 2015. Available at: https:// www.nytimes.com/2015/08/23/magazine/theunwelcome-return-of-illegals.html? mcubz $=0 \& \_r=0$. Accessed on July 29, 2017.
The New York Times. 2017. A Guide to Joe Arpaio, The Longtime Sherriff Who Escaped Strife. August, 27, 2017. Available at: https:// www.nytimes.com/2017/08/27/us/joe-arpaiosheriff-pardon.html? $\backslash \mathrm{mcubz}=0$. Accessed on May 27, 2017.

Think Progress. 2015. The Dehumanizing History of the Words We use to Describe Immigrants. August 13, 2015. Available at: https:// thinkprogress.org/the-dehumanizing-history-ofthe-words-weve-used-to-describe-immigrants18dd39c90459/. Accessed on August 1, 2017. 